\title{
$=$

\section{PENGARUH PROPORSI PATI BENGKUANG DAN TEPUNG KENTANG TERHADAP HASIL JADI MASKER UNTUK PERAWATAN KULIT WAJAH}

\section{Vitri Amalia}

Program Studi Pendidikan Tata Rias dan Kecantikan, Fakultas Pariwisata dan Perhotelan, Universitas Negeri Padang email : vitriamalia25@gmail.com

\section{Linda Rosalina}

Program Studi Pendidikan Tata Rias dan Kecantikan, Fakultas Pariwisata dan Perhotelan, Universitas Negeri Padang

email : roselind_sweety@yahoo.com

Facial skin problems such as blemishes, black spots, dull skin, premature aging and so on, require more optimal treatment, one of them using a mask Facial skin masks are one type of traditional cosmetics that can be used as a facial treatment to maintain the health of facial skin, namely by using yam starch and potato flour. The purpose of this study was to describe the various proportions of the results of the yam starch mask and potato flour with indicators of aroma, stickiness and panelist preference level and to analyze comparisons to assess the best proportion. This research is a research with true experimental method. The oup consisted of the results of the masked starch mask and potato flour with the proportion of $10 \mathrm{~g}$ and $40 \mathrm{~g}$ (X1), the proportion of $20 \mathrm{~g}$ and $30 \mathrm{~g}(X 2)$ and the proportion of $30 \mathrm{~g}$ and $20 \mathrm{~g}$ (X3). The type of data used in this study is primary data. Data analysis techniques using ANOVA analysis and using Duncan's analysis as a further test. The results of the hypothesis test state that the price of $F$ count $>F$ table $(27,271>3,110)$ this proves that the hypothesis that reads "There are differences in the proportion of yam and potato starch (10g: $40 \mathrm{~g}),(20 \mathrm{~g}: 30 \mathrm{~g})$ and (30g: 20g) starch on the results of the facial skin care mask seen from the aroma, stickiness, and level panelist's preference "received at 95\% significancy.

Keywords: masks, starch, potato 


\section{PENDAHULUAN}

Wajah merupakan bagian tubuh yang menggambarkan keseluruhan kondisi seseorang. Perawatan kulit wajah merupakan hal yang paling utama yang perlu diperhatikan dalam tata kecantikan kulit. Hayatunnufus (2005:5) menyatakan bahwa " kulit wajah yang sehat memiliki kriteria yaitu elastis atau lentur, lembut, warna kulit bercahaya dan jenis kulit normal". Setiap individu memiliki jenis kulit wajah berbeda, karena dipengaruhioleh kadar air dan produksi minyak dalam kulit, kecepatan pergantian sel-sel lapisan tanduk, dan faktor lingkungan (Sukmawati, 2013:35). Jika perawatan kulit wajah tidak dilakukan dengan benar maka akan timbul masalah kulit seperti kulit kusam, jerawat, bintik kemerah merahan dan kulit kering/kusam, sehingga banyak wanita kurang rasa percaya diri.

Kulit wajah manusia dikelompokkan menjadi lima jenis yaitu kulit normal, kombinasi, berminyak, kering, dan sensitif. Kulit normal ditandai dengan kulit tidakberminyak dan tidak kering, sehingga kelihatan segar dan bagus, pori-pori hampir tidak kelihatan. Pengeluaran kotoran dan penyerapan zat-zat yang berguna melalui kulit serta peredaran darah yang berjalan dengan baik, akan jarang mendapat gangguan jerawat maupun timbulnya cacat-cacat pada kulit muka dan tonusnya baik. Masalah pada kulit dapat ditimbulkan oleh bakteri, jamur atau virus yang dapat menyebabkan terjadinya infeksi kulit (Santoso, 2012: 136).

Pada usia muda, kulit baru akan muncul ke lapisan epidermis setiap 14-28 hari (Tilaar, 2012: 53). Penuaan dini rentan terjadi pada usia 18-21 tahun. Dengan bertambahnya usia, proses regenerasi berkurang secara cepat, permasalahan kulit wajah semakin terlihat seperti kulit kusam, noda bekas jerawat, flek hitam, kerutan dan lain sebagainya, sehingga dibutuhkan perawatan ekstra untuk menangani permasalahan tersebut.

Perawatan dibedakan menjadi 2 yaitu perawatan secara lengkap dan perawatan sehari-hari (Setijani, 2002: 1). Perawatan secara lengkap dilakukan di klinik dan dilakukan oleh ahli kecantikan, sedangkan perawatan seharihari adalah perawatan yang dapat dilakukan sendiri, misalnya dengan membuat masker tradisional. Masker wajah memiliki manfaat yaitu memberi kelembaban, memperbaiki tekstur kulit, meremajakan kulit, mengencangkan kulit, menutrisi kulit, melembutkan kulit, membersihkan pori-pori kulit, mencerahkan warna kulit, merilekskan otot-otot wajah dan menyembuhkan jerawat (Fauzi, 2012: 155).

Menurut Primadiati (2001: 185) Jenisnya masker terbagi dua yaitu 1) setting mask dan

2) non-setting mask. Setting mask merupakan jenis masker dengan bahan dasar kimia yaitu kaolin. Kaolin yaitu tepung warna putih mempunyai efek lebih kuat dari pada magnesium karbonat (sebagai

astringentringan yang cocok untuk memperbaiki kulit yang berpori-pori terbuka serta mengencangkan kulit). Serta berfungsi membersihkan kulit, membersihkan sirkulasi dan merupakan sumber nutrisi kulit.Masker adalah perawatan yang ditujukan untuk mengencangkan tonus (daya bingkis) kulit serta merawat kulit dengan kandungan bahan yang terdapat dalam kosmetik, untuk perawatan muka / kulit wajah yang memiliki manfaat yaitu memberi kelembaban, merangsang sel sel kulit, mengeluarkan kotoran dan sel sel tanduk yang melekat dikulit, menormalkan kulit dari gangguan jerawat, bintik hitam dan mengeluarkan lemak yang berlebih pada kulit, mencegah, mengurangi keriput dan hyperpigmentasi dan melancarkan peredaran darah (Rostamilis, 2005: 152).

Salah satunya yaitu dengan 
menggunakan bengkuang (pachyrhizus erosus) merupakan umbi yang memiliki kandungan-kandungan zat yang bermanfaat. Kandungan zat meliputi antioksidan, vitamin C, air, antibakteri dan flavanoid. Flavanoid merupakan tabir surya alami untuk mencegah kerusakan kulit akibat radikal bebas dan zat fenolik efektif untuk menghambat proses pembentukan melanin (Putra, 2012:23).

Dalam satu umbi bengkuang terdapat kandungan $40 \%$ vitamin C dan sisanya adalah air dan serat. Pati bengkoang adalah zat pati dari umbi bengkoang yang didapatkan dari proses pengendapan air bengkuang. Pati yang bewarna putih bersifat dingin dan menyejukkan sehingga dapat digunakan untuk mendinginkan lapisan kulit yang telah terken sinar matahari (Deiner dalam Anjani, 2008:1)

Selain bengkuang ada beberapa bahan alami lain untuk mencerahkan kulit wajah yaitu kentang. Kentang dikenal sebagai bahan makanan yang kaya akan karbohidrat. Umbi yang mempunyai nama latin Solanum Tuberosum L. Dalam penelitian menurut Laurencius (2012), Kandungan kentang yaitu enzim catecholase berfungsi untuk menghilangkan noda hitam pada wajah dan menjadikan lebih cerah pada wajah apabila digunakan sebagai masker wajah. Selain bagian isi, kulitnya pun bermanfaat, karena bagian kulit kaya akan asam klorogenik yaitu polifenol yang mencegah mutasi sel-sel yang mengarah pada kanker. Karena di dalam kulitkentang mempunyai aktivitas sebagai antioksidan yang dapat menetralkan radikal bebas yang dapat merusak sel-sel jaringan kulit. Sama halnya dengan bengkuang, kentang pun memiliki kadar air yang cukup tinggi sekitar $80 \%$, sumber vitamin C serta $B 1$. selain itu warna kuning pada kentang karena mengandung beta karoten yang berfungsi sebagai zat antioksidan.

Menurut kamus besar bahasa Indonesia (KBBI) proporsi adalah perbandingan. Proporsi adalah istilah yang sering di ucapkan oleh beberapa orang yang sering melakukan pengamatan terhadap objek tertentu. Proporsi merupakan suatu keseimbangan antara suatu benda dengan benda lainnya dalam berbagai pertimbangan. Jadi pengertian proporsi adalah keseimbangan yang harus dimiliki oleh suatu objek dengan perbandingan objek lainnya.

Dari uraian diatas dapat disimpulkan bahwa Pati bengkuang dan tepung kentang di duga dapat mengatasi beberapa permasalahan kulit wajah karena di dalamnya terdapat beberapa zat yang bermanfaat seperti flavonoid, vitamin c dan B1, saponin, zat fenolik, dan polifenol yang dapat digunakan untuk perawatan kulit wajah.

Oleh karena itu peneliti ingin memanfaatkan pati bengkuang dan tepung kentang sebagai bahan pembuat masker yang dilihat dari sifat fisik (meliputi: aroma, daya lekat dan tingkat kesukaan panelis) dengan komposisi (10g:40g), (20g:30g),dan (30g:20g). Dari beberapa permasalahan diatas penulis tertarik untuk mezneliti "Pengaruh Proporsi Pati Bengkuang dan Tepung Kentang Terhadap Hasil Jadi Masker Untuk Perawatan Kulit Wajah".

\section{METODE}

Penelitian ini adalah penelitian kuantitatif. Dengan desain penelitian true experimen (experimen sesungguhnya). Tempat dan waktu penelitian dilakukan di Workshop Program Studi Pendidikan Tata Rias dan Kecantikan, Fakultas Pariwisata dan Perhotelan, Universitas Negeri Padang pada tanggal 26 September 2018. Untukmemperoleh data dalam penelitian ini dari observasi yang diberikan kepada sepuluh orang panelis dua dosen dan delapan orang mahasiswa dengan memberikan lembaran penilaian. Teknik analisis data dilakukan dengan menggunakan menggunakan uji analisis varians (anava).

\section{HASIL DAN PEMBAHASAN}

\author{
A. Hasil \\ 1. Deskripsi Hasil jadi penggunaan pati \\ bengkuang $10 \mathrm{~g}$ dengan $40 \mathrm{~g}$ tepung kentang $\left(X_{1}\right)$
}

Tabel 1. Distribusi Hasil Jadi Penggunaan Pati Bengkuang 10g Dengan 40g Tepung Kentang $\left(X_{1}\right)$ 


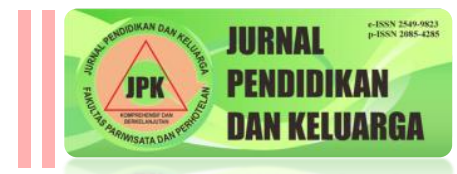

\begin{tabular}{|l|l|l|}
\hline Indikator & $\begin{array}{l}\text { Skor } \\
\text { rata-rata }\end{array}$ & Kategori \\
\hline $\begin{array}{l}\text { Aroma } \\
\text { Kentang }\end{array}$ & 1,3 & $\begin{array}{l}\text { Beraroma } \\
\text { Kentang Kuat }\end{array}$ \\
\hline Daya Lekat & 2.7 & Cukup Lekat \\
\hline $\begin{array}{l}\text { Tingkat } \\
\text { Kesukaan }\end{array}$ & 1.9 & Kurang Suka \\
\hline
\end{tabular}

Dari tabel di atas dapat dilihat bahwa hasil jadi penggunaan pati bengkuang $10 \mathrm{~g}$ dengan $40 \mathrm{~g}$ tepung kentang $\left(X_{1}\right)$ berdasarkan pendapat panelis memiliki skor rata-rata 1,3 dengan kategori masker yang dihasilkan beraroma kentang kuat, skor ratarata 2,7 dengan kategori cukup lekat, dan memiliki tingkat kesukaan 1,9 berkategori kurang suka.

2. Deskripsi Hasil jadi penggunaan pati bengkuang $20 \mathrm{~g}$ dengan $30 \mathrm{~g}$ tepung kentang $\left(X_{2}\right)$

Tabel 2. Distribusi Hasil Jadi Penggunaan Pati Bengkuang 20g Dengan 30g Tepung Kentang $\left(X_{2}\right)$

\begin{tabular}{|l|l|l|}
\hline Indikator & $\begin{array}{l}\text { Skor } \\
\text { rata- rata }\end{array}$ & Kategori \\
\hline Aroma Kentang 2.8 & $\begin{array}{l}\text { Cukup } \\
\text { Beraroma } \\
\text { Kentang }\end{array}$ \\
\hline Daya Lekat & 3.6 & Lekat \\
\hline $\begin{array}{l}\text { Tingkat } \\
\text { Kesukaan }\end{array}$ & 3.7 & Suka \\
\hline
\end{tabular}

Dari tabel di atas dapat dilihat bahwa hasil jadi penggunaan pati bengkuang $20 \mathrm{~g}$ dengan $30 \mathrm{~g}$ tepung kentang $\left(X_{2}\right)$ berdasarkan pendapat panelis memiliki skor rata-rata 2.8 dengan kategori masker yang dihasilkan cukup beraroma kentang, skor rata-rata 3.6 dengan kategori lekat, dan memiliki tingkat kesukaan 3.7 berkategori suka.

3. Deskripsi Hasil jadi Penggunaan Pati Bengkuang 30g dengan 20g Tepung Kentang $\left(X_{3}\right)$

Tabel 3. Distribusi Hasil Jadi Penggunaan Pati Bengkuang 30g Dengan 20g Tepung Kentang $\left(X_{3}\right)$

\begin{tabular}{|l|l|l|}
\hline Indikator & $\begin{array}{l}\text { Skor rata- } \\
\text { rata }\end{array}$ & Kategori \\
\hline Aroma Kentang & 3.8 & $\begin{array}{l}\text { Tidak } \\
\text { Beraroma } \\
\text { Kentang }\end{array}$ \\
\hline Daya Lekat & 2.2 & Kurang Lekat \\
\hline $\begin{array}{l}\text { Tingkat } \\
\text { Kesukaan }\end{array}$ & 2.7 & Cukup Suka \\
\hline
\end{tabular}

Dari tabel di atas dapat dilihat bahwa hasil jadi penggunaan pati bengkuang 30gdengan 20g tepung kentang $\left(X_{3}\right)$ berdasarkan pendapat panelis memiliki skor rata-rata 3.8 dengan kategori masker yang dihasilkan tidak beraroma kentang, skor rata-rata 2.2 dengan kategori kurang lekat, dan memiliki tingkat kesukaan 2.7 berkategori cukup suka.

B. Uji Persyaratan Analisis

1. Uji Normalitas

Tabel 4. Uji Normalitas Pada Ketiga Kelompok

One-Sample Kolmogorov-Smirnov Test

\begin{tabular}{|c|c|c|c|}
\hline & $X 1$ & $x 2$ & $x 3$ \\
\hline$N$ & 30 & 30 & 30 \\
\hline Normal & 1.96 & 3.36 & 2.900 \\
\hline Parameters ${ }^{a}$ & 67 & 67 & \\
\hline Deviatio & $\begin{array}{l}.764 \\
89\end{array}$ & $\begin{array}{l}.614 \\
05\end{array}$ & .8448 \\
\hline$n$ & & & \\
\hline $\begin{array}{l}\text { Most Extreme Absolut } \\
\text { Differences } e\end{array}$ & .217 & .291 & .214 \\
\hline Positive & .216 & .291 & .190 \\
\hline Negativ & -.217 & -.282 & -.214 \\
\hline Kolmogorov-Smirnov Z & 1.191 & $\begin{array}{l}1.59 \\
5\end{array}$ & 1.171 \\
\hline Asymp. Sig. (2-tailed) & .117 & .212 & .129 \\
\hline Tes & & & \\
\hline
\end{tabular}

Berdasarkan uraian di atas didapatkan semua uji mempunyai nilai $p>0,05$, hal ini menunjukkan data berdistribusi normal.

\section{Uji Homogenitas}

Tabel 5. Uji Normalitas Pada Ketiga Kelompok Test of Homogeneity of Variances Skor 
Berdasarkan uraian di atas didapatkan semua uji mempunyai nilai $p>0,05$, hal ini menunjukkan data homogen.

\section{Pengujian Hipotesis}

Tabel 6. Hasil Analisis Data

Pengujian Hipotesis

ANOVA

\begin{tabular}{|l|l|l|l|l|l|}
\hline Skor & & & & & \\
\hline & $\begin{array}{l}\text { Sum of } \\
\text { Square } \\
\text { S }\end{array}$ & $\begin{array}{l}\text { Mean } \\
\text { Df }\end{array}$ & Square & $F$ & Sig. \\
\hline $\begin{array}{l}\text { Between } \\
\text { Groups } \\
\text { Within } \\
\text { Groups } \\
\text { Total }\end{array}$ & 30.489 & 2 & 15.244 & 27.27 & 1 \\
\hline
\end{tabular}

Data di atas menunjukkan bahwa nilai $F$ hitung adalah sebesar (27.271), sedangkan nilai $F$ tabel untuk ketentuan df $1=2$ dan df $2=87$ pada taraf signifikansi 5\% adalah sebesar (3.110). Dengan demikian harga $F_{\text {hitung }}>F_{\text {tabel }}(27.271>3.110)$ hal ini membuktikan bahwa hipotesis yang berbunyi “ Terdapat perbedaan hasil proporsi pati bengkuang dan tepung kentang (10g:40g), (20g:30g) dan (30g:20g) terhadap hasil jadi masker perawatan kulit wajah dilihat dari aroma, daya lekat, dan tingkat kesukaan panelis" diterima pada taraf signifikansi $95 \%$.

\section{Tabel 6. Hasil Analisis Uji Duncan}

\section{Skor Duncan}

\begin{tabular}{|l|l|l|l|}
\hline $\begin{array}{l}\text { Levene } \\
\text { Statistic }\end{array}$ & $d f 1$ & $d f 2$ & Sig. \\
\hline .601 & 2 & 87 & .550 \\
\hline
\end{tabular}

Means for groups in homogeneous subsets are displayed.

Berdasarkan analisis Uji Duncan di atas maka dapat dijelaskan bahwa kelompok penggunaan pati bengkoang $10 \mathrm{~g}$ dengan $40 \mathrm{~g}$ tepung kentang $\left(X_{1}\right)$ dengan rata-rata (1.966)berbeda secara signifikan dengan kelompok penggunaan pati bengkuang $30 \mathrm{~g}$ dengan $20 \mathrm{~g}$ tepung kentang $\left(X_{3}\right)$ dengan rata-rata
(2.900) dan berbeda signifikan dengan penggunaan pati bengkuang $20 \mathrm{~g}$ dengan $30 \mathrm{~g}$ tepung kentang $\left(X_{2}\right)$ dengan nilai rata-rata (3.366), sedangkan kelompok data yang memiliki skor tertinggi adalah penggunaan pati bengkuang $20 \mathrm{~g}$ dengan $30 \mathrm{~g}$ tepung kentang dengan rata- rata hasil pencapaian indikator aroma, daya lekat dan tingkat kesukaan tertinggi dari dua kelompok lainnya.

\section{B. Pembahasan}

Berdasarkan hasil penelitian yang telah dideskripsikan di atas maka dapat dijelaskan pembahasan bahwa hasil jadi penggunaan pati bengkuang $10 \mathrm{~g}$ dengan $40 \mathrm{~g}$ tepung kentang $\left(X_{1}\right)$ berdasarkan pendapat panelis memiliki skor ratarata 1,3 dengan kategori masker yang dihasilkan beraroma kentang kuat, skor rata-rata 2,7 dengan kategori cukup lekat, dan memiliki tingkat kesukaan 1,9 berkategori kurang suka, hasil jadi penggunaan pati bengkuang $20 \mathrm{~g}$ dengan $30 \mathrm{~g}$ tepung kentang $\left(X_{2}\right)$ berdasarkan pendapat panelis memiliki skor rata-rata 2.8 dengan kategori masker yang dihasilkan cukup beraroma kentang, skor rata-rata 3.6 dengan kategori lekat, dan memiliki tingkat kesukaan

3.7 berkategori suka. hasil jadi penggunaan pati bengkuang $30 \mathrm{~g}$ dengan $20 \mathrm{~g}$ tepung kentang $\left(X_{3}\right)$ berdasarkan pendapat panelis memiliki skor ratarata 3.8 dengan kategori masker yang dihasilkan tidak beraroma kentang, skor rata-rata 2.2 dengan kategori kurang lekat, dan memiliki tingkat kesukaan

2.7 berkategori cukup suka.

Hasil uji hipotesis menyatakan bahwa harga $F_{\text {hitung }}$ $>F$ tabel $(27.271$ > 3.110) hal ini membuktikan bahwa hipotesis yang berbunyi “ Terdapat perbedaan hasil proporsi pati bengkuang dan tepung kentang (10g:40g), (20g:30g) dan (30g:20g) terhadap hasil jadi masker perawatan kulit wajah dilihat dari aroma, daya lekat, dan tingkat kesukaan panelis" diterima pada taraf signifikansi 95\%. Uji lanjut dengan Uji Duncan menyatakan hasil bahwa ketiga kelompok memiliki perbedaan secara signifikan dan proporsi terbaik adalah penggunaan pati bengkoang $20 \mathrm{~g}$ dengan $30 \mathrm{~g}$ tepung kentang dengan rata- rata hasil pencapaian indikator aroma, daya lekat dan tingkat kesukaan yang di sukai dari dua kelompok lainnya.

Berbedanya hasil pada indikator aroma, daya lekat dan tingkat kesukaan panelis adalah sebagai 
pengaruh dari berbedanya proporsi dan perbandingan proporsi pati bengkuang dan tepung kentang yang ada didalam masing-masing kelompok sampel. Berdasarkan analisis diketahui bahwa kelompok dengan perbandingan penggunaan pati bengkuang $20 \mathrm{~g}$ dengan $30 \mathrm{~g}$ tepung kentang memiliki hasil yang lebih bagus dari dua kelompok lainnya.

Pada indikator aroma kentang yang dapat tercium oleh panelis terdapat hasil bahwa kelompok X3 memiliki skor paling tinggi dibandingkan dengan kelompok X1 dan X2 karena dipahami bahwa perbadingan jumlah kentang pada $X 3$ lebih sedikit yaitu $20 \%$, sedangkan proporsi bengkuang yang tidak memiliki bau setelah diolah menjadi masker tidak mempengaruhi hasil akhir masker yang dibuat. Karena penciuman manusia dapat mempengaruhi kesukaan akan sesuatu maka dalam membuat masker untuk perawatan harus mempertimbangkan aroma yang dapat mempengaruhi pemakainya.

Namun dari penilaian indikator daya lekat masker kelompok $X_{2}$ memiliki skor yang lebih tinggi, hal ini didukung pula oleh tingkat kesukaan yang dirasakan oleh panelis terhadap masker, kelompok $X_{2}$ tetap memiliki persentase hasil yang lebih tinggi. Hal ini berarti bahwa kelompok eksperimen 2 dengan proporsi penggunaan pati bengkuang $20 \mathrm{~g}$ dengan $30 \mathrm{~g}$ tepung kentang memiliki hasil yang lebih baik dibandingkan dengan proporsi dua kelompoklainnya.

Pentingnya menciptakan kosmetika yang memiliki tingkat kesukaan oleh konsumen yang menggunakan, sebagai upaya membantu para pengguna kosmetika untuk memilihkan kosmetika yang bermanfaat seperti penggunaan masker wajah. Menurut Rostamailis (2005:150) "masker merupakan bahan kosmetik yang digunakan pada akhir perawatan kulit wajah/ kulit tubuh, sesudah pembersihan total dari massage". Lebih jauh Hayatunnufus (2009: 100) menjelaskan fungsi masker 1) sebagai pelembut, 2) Melenyapkan kesuraman kulit, 3) Menggugurkan sel-sel yang sudah tua dan mati, 4) Menyegarkan kulit, 5) Mengencangkan kulit dan mencegah keriput pada wajah, 6) Menutup pori-pori dan memutihkan kulit, 7) Menormalkan kulit dari gangguan jerawat, 8) Meningkatkan taraf kebersihan.

Manfaat yang dapat dirasakan oleh seseorang saat menggunakan masker wajah tentu dipengaruhi oleh kandungan bahan yang ada didalam kosmetika tersebut. Seperti hasil penelitian yang telah dilakukan ini, peneliti menggunakan dua kandungan bahan alami yakni pati bengkuang dan tepung kentang yang secara teoritis memiliki kandungan bahan yang bermanfaat untuk kecantikan kulit.

Deiner dalam Anjani (2008:1) menyatakan bahwa "Dalam satu umbi bengkuang terdapat kandungan $40 \%$ vitamin C dan sisanya adalah air dan serat. Pati bengkuang adalah zat pati dari umbi bengkuang yang didapatkan dari proses pengendapan air bengkuang. Pati yang bewarna putih bersifat dingin dan menyejukkan sehingga dapat digunakan untuk mendinginkan lapisan kulit yang telah terken sinar matahari. Sedangkan Kentang (Solanum Tuberosum L) Dalam penelitian menurut Laurencius (2012) menyatakan bahwa kandungan kentang yaitu enzim catecholase berfungsi untuk menghilangkan noda hitam pada wajah dan menjadikan lebih cerah pada wajah apabila digunakan sebagai masker wajah. Selain bagian isi, kulitnya pun bermanfaat, karena bagian kulit kaya akan asam klorogenik yaitu polifenol yang mencegah mutasi sel-sel yang mengarah pada kanker.

Besarnya manfaat yang dapat dirasakan oleh pengguna masker tradisional ini disebabkan oleh bahan alami tanpa zat pengawet serta bebas bahan kimia yang dapat menjaga kesehataan kulit wajah engguna kosmetika tradisional ini. Berdasarkan hasil penelitian ini maka peneliti dapat menyarankan masyarakat untuk menggunakan pati bengkuang dan tepung kentang untuk masker wajah dengan proporsi $20 \mathrm{~g}$ pati bengkuang dan $30 \mathrm{~g}$ tepung kentang untuk hasil daya lekat yang lebih baik dan tingkat kesukaan yang lebih baik.

\section{PENUTUP}

\section{Simpulan}

\section{Simpulan}

Berdasarkan hasil penelitian maka dapat disimpulkan sebagai berikut :

1. Hasil jadi penggunaan pati bengkuang $10 \mathrm{~g}$ dengan $40 \mathrm{~g}$ tepung kentang $\left(X_{1}\right)$ memiliki hasil masker yang beraroma kentang kuat, cukup lekat, namun tingkat kesukaan berkategori kurang suka.

2. Hasil jadi penggunaan pati 
bengkuang $20 \mathrm{~g}$ dengan $30 \mathrm{~g}$ tepung kentang $\left(X_{2}\right)$ memiliki hasil masker yang cukup beraroma kentang, lekat, dan memiliki tingkat kesukaan berkategori suka.

3. Hasil jadi penggunaan pati bengkuang $30 \mathrm{~g}$ dengan $20 \mathrm{~g}$ tepung kentang $\left(X_{3}\right)$ memiliki hasil masker yang tidak beraroma kentang, kurang lekat, dan memiliki tingkat kesukaan berkategori cukup suka.

4. Hasil uji hipotesis menyatakan bahwa harga $F_{\text {hitung }}>F_{\text {tabel }}(27.271>3.110)$ hal ini membuktikan bahwa hipotesis yang berbunyi “ Terdapat perbedaan hasil proporsi pati bengkuang dan tepung kentang (10g:40g), (20g:30g) dan (30g:20g) terhadap hasil jadi masker perawatan kulit wajah dilihat dari aroma, daya lekat, dan tingkat kesukaan panelis" diterima pada taraf signifikansi $95 \%$.

\section{Saran}

Setelah melakukan penelitian ini maka dapat dikemukan beberapa saran yang diberikan kepada penerima manfaatpenelitian, yakni kepada pihakpihak:

1. Kepada Prodi Pendidikan Tata rias dan kecantikan Fakultas Pariwisata dan Perhotelan, hasil dari penelitian ini dapat menjadi masukan sebagai referensi bahan pada mata kuliah Perawatan Kulit Wajah dan Penelitian Rias dengan merekomendasikan temuan masker tradisional dengan proporsi $20 \mathrm{~g}$ pati bengkuang dan $30 \mathrm{~g}$ tepung kentang.

2. Kepada mahasiswa tata rias dan kecantikan yang melakukan perawatan kulit wajah dapat merekomendasikan penggunaan kosmetika tradisional berupa temuan masker tradisional dengan proporsi $20 \mathrm{~g}$ pati bengkuang dan $30 \mathrm{~g}$ tepung kentang.

3. Kepada masyarakat yang memiliki masalah dengan kulit wajah dapat memanfaatkan penggunaan temuan masker tradisional dengan proporsi $20 \mathrm{~g}$ pati bengkuang dan $30 \mathrm{~g}$ tepung kentang untuk meningkatkan kecerahan kulit wajah dengan bahan alami tanpa bahan pengawet dan zat kimia.

4. Penelitian ini bermanfaat untuk peneliti sendiri dalam meningkatkan wawasan untuk menjadi praktisi dalam bidang kecantikan khususnya dalam melaksanakan kompetensi pada perawatan kulit wajah.

\section{DAFTAR PUSTAKA}

Hayatunnufus. 2009. Perawatan Kulit Wajah. Padang: UNP Press

Sukmawati, 2016. Ilmu Penyakit Kulit dan Kelamin. Jakarta: Sagung Seto

Santoso, Budi. 2012. Buku Pintar Perawatan Kulit Terlengkap. Jogjakarta: Buku Biru

Tilaar, Martha. 2012. Facial Pedia. Salon Pro: Jakarta

Setijani, 2002. Perawatan Kulit Wajah Berproblem. Jakarta. (PPPG). Kejuruan

Fauzi. 2012. Merawat Kulit dan Wajah.

Primadiati, Rahmi. 2001. Kecantikan, Kosmetika dan Estetika: Pedoman Instruksional Program CIDESCO Internasional. Jakarta: Gramedia Pustaka Utama

Rostamailis. 2005. Perawatan Badan, Kulit, dan Rambut. PT Rinika Cipta: Jakarta

Putra, Sitiatava Rizema. 2012. Optimalkan Kesehatan Wajah dan Kulit Dengan Bengkuang. Yogyakarta: Diva Press

Deiner, Anjani. 2008. Formula Bath Gel Bengkuang-Madu. Bogor: Institut Pertanian Bogor

Lukitaningsih, Endang. 2009. The Exploration of Whitening and Sun Screening Compounds In Bengkoang Roots (Pachyrhizus Erosus) Jerman: University Wursburg Jerman 